\title{
In vitro growth-inhibitory effect of Brazilian plants extracts against Paenibacillus larvae and toxicity in bees
}

\author{
MARIANA PIANA ${ }^{1}$, THIELE F. DE BRUM ${ }^{1}$, ALINE A. BOLIGON ${ }^{1}$, \\ CAMILLA F.S. ALVES ${ }^{1,2}$, ROBSON B. DE FREITAS ${ }^{1}$, LETÍCIA T. NUNES ${ }^{1}$, \\ NATALIA J. MOSSMANN ${ }^{1}$, VANESSA JANOVIK ${ }^{1}$, ROBERTA S. JESUS ${ }^{1}$, \\ RODRIGO A. VAUCHER ${ }^{2}$, ROBERTO C.V. SANTOS ${ }^{2}$ and MARGARETH L. ATHAYDE ${ }^{1}$ \\ ${ }^{1}$ Laboratório de Fitoquímica, Departamento de Farmácia Industrial, Universidade Federal de \\ Santa Maria/UFSM, Av. Roraima, 26, Sala 1115, 97105-900 Santa Maria, RS, Brasil \\ ${ }^{2}$ Laboratório de Microbiologia Clínica, Ciências da Saúde, Centro Universitário Franciscano/UNIFRA, \\ Rua dos Andradas, 1614, Prédio 4, Sala 115, 97010-032 Santa Maria, RS, Brasil
}

Manuscript received on July 3, 2014; accepted for publication on December 23, 2014

\begin{abstract}
American foulbrood (AFB) is a serious worldwide spreading disease in bees caused by Paenibacillus larvae. Plants extracts are known to decrease or inhibit the growth of these bacteria. The purpose of this study was to evaluate the antimicrobial activity of Calendula. officinalis, Cariniana domestica, and Nasturtium officinale extracts against the P. larvae and to evaluate the toxicity of the extracts in bees. In vitro activity against $P$. larvae of the extracts was evaluated by micro dilution method and the minimal inhibitory concentrations (MICs) were also determined. The concentrations used in the toxicity test were established based on the MIC values and by the spraying application method. The P. larvae was susceptible to the evaluated crude extract of $C$. officinalis and $N$. officinale. To $C$. domestica, only the ethyl acetate (EtAc) fraction and $n$-butanol $(\mathrm{BuOH})$ fractions had activity against $P$. larvae. Toxicity analysis in bees showed no toxicity for $N$. officinale crude extract and for $C$. domestica $\mathrm{BuOH}$ fraction during 15 days of treatment, however, some deaths of bees occurred during the first three days of treatment with $C$. officinalis and $C$. domestica EtAc fraction. The results with these species were firstly described and showed that $N$. officinale crude extract and $C$. domestica $\mathrm{BuOH}$ fraction both presented not toxic effects in the concentration tested by the spraying application method, and can be a useful alternative for treatment or prevention of AFB.
\end{abstract}

Key words: Antibacterial activity, American foulbrood, Brazilian plants, Paenibacillus larvae.

\section{INTRODUCTION}

American foulbrood (AFB) is a serious worldwide spreading disease of honey bee (Apis mellifera) caused by the spore-forming, Gram-positive bacterium Paenibacillus larvae (Eguaras et al. 2005, Flesar et

Correspondence to: Mariana Piana

E-mail address: marianarpiana@gmail.com al. 2010). AFB is highly infectious and can be fatal to colonies. At a minimum it decreases honey productivity of colonies and increases labor and treatment costs to beekeepers to control disease transmission (Hansen and Brødsgaard 1999, Bastos et al. 2008).

The popular approach in treatment of AFB in some countries, such as the US, is to suppress the 
clinical phase of the disease with supplemented antibiotics, however, this practice has been shown to lead to bacterial resistance (Eguaras et al. 2005, Flesar et al. 2010) such as tetracycline in which vegetative cells of $P$. larvae have become increasingly resistant to treatments (Kochansky et al. 2001, Cox et al. 2005). Furthermore, antibiotic residues are found in honey and its use in the colony can also contaminate royal jelly (Bogdanov 2006).

This situation calls for an alternative and effective control of the disease with either therapeutics or prophylactic feed additives that do not contribute to the phenomenon of bacterial resistance (Lewis and Ausubel 2006, Flesar et al. 2010).

Plant extracts, herbs, spices, essential oils and isolated compounds are known to delay or inhibit the growth of bacteria, yeast and moulds (Hayouni et al. 2008, Boligon et al. 2013). Brazil has in its flora, species with antimicrobial activity such as Calendula officinalis L. known in Brazil as calendula (Efstratiou et al. 2012), Cariniana domestica (Mart.) Miers. known as jequitibá-roxo (Janovik et al. 2009), and Nasturtium officinale commonly called agrião (Antúnez et al. 2008). Studies conducted by Boligon et al. (2013) showed positive results of Scutia buxifolia extract against $P$. larvae as well as low toxicity to bees. In addition Copaifera officinalis (copaiba) oil in studies by Santos et al. (2012), have also presented similar results.

The aim of the present work was to evaluate the antimicrobial activity of $C$. officinalis, $C$. domestica and $N$. officinale extracts against the etiologic agent of American Foulbroad Disease, the $P$. larvae. Furthermore, the toxicity of the extracts in honey bees A. Mellifera was also evaluated.

\section{MATERIALS AND METHODS}

\section{Plant Collection AND EXTRACTION}

The C. officinalis (flowers) and $N$. officinale produced in a hydroponic system (leaves and branches) used in this study were purchased in supermarkets in the city of Santa Maria-RS, Brazil. The $C$. domestica (leaves) were collected in Tangará-da-Serra, Mato Grosso do Sul, Brazil. Exsiccate of $C$. domestica was archived as voucher specimen in the herbarium of the Department of Pharmacology at UFSM (SMDB 11818). The vegetables were cleaned and dried at room temperature. The dried plants were powdered in a knife mill and the powder was macerated with $70 \%$ ethanol for a week with daily shake-up. The extract was filtered and concentrated under reduced pressure in rotary evaporator (temperature $\pm 40^{\circ} \mathrm{C}$ ) in order to eliminate the ethanol, then the aqueous extract was dried, thus obtaining the crude extract.

For the $C$. domestica, an equal part of aqueous extract was partitioned with solvents of increasing polarity dichloromethane (DCM), ethyl acetate (EtAc) and $n$-butanol $(\mathrm{BuOH})$ and were also dried to provide each corresponding fraction.

\section{MICROORGANISM TESTED}

In this study, $P$. larvae (ATCC 9545) from the collection of the Ministry of Agriculture (LANAGRO/RS) Brazil was used. The microorganism was grown in Mueller-Hinton broth (Difco, Sparks, Maryland, USA) at $37^{\circ} \mathrm{C}$ for $24 \mathrm{~h}$ and maintained on slopes of nutrient agar (Difco).

DETERMINATION OF THE MINIMUM INHIBITORY

\section{CONCENTRATION}

The minimum inhibitory concentrations (MICs) of C. officinalis, $N$. officinale and C. domestica crude extracts and $C$. domestica fractions were determined by microdilution techniques in Mueller-Hinton broth (Difco) for P. larvae (CLSI 2008). The assay was carried out in 96-well microtitre plates. Each sample was mixed with an inoculum prepared in the same medium at a density adjusted per tube to 0.5 of the McFarland scale $\left(1.5 \times 10^{8} \mathrm{CFU} / \mathrm{mL}\right)$ and diluted 1:10 for the broth microdilution procedure. Microtitre trays were incubated at $37^{\circ} \mathrm{C}$ and the MICs were recorded after $24 \mathrm{~h}$ of incubation. The 
MIC was defined as the lowest concentration of compounds that inhibit bacterial growth. This test was performed in triplicate on separate occasions. The 2,3,5-triphenyltetrazolium chloride was used as an indicator of bacterial growth.

\section{TOXICITY ASSAY}

The C. officinalis and N. officinale crude extracts, and EtAc and $\mathrm{BuOH}$ fractions of $C$. domestica were dissolved in DMSO. The concentrations used in the toxicity assay were determined based on the MIC values. The spraying application method was performed according to Santos et al. (2012). Petri dishes (150 x $15 \mathrm{~mm})$ padded with absorbent filter paper on the inner bottom and with an extra lid of plastic mesh were used. Fifteen adult worker bees were placed in every modified Petri dish. Then, $1 \mathrm{~mL}$ of each concentration (crude extracts or fractions) was individually sprayed on the bees throughout the plastic lid using a hand sprayer. A device with candy and water was placed inside each unit as food for the bees. Fifteen bees in a modified Petri dish sprayed with DMSO were included as negative control, and six bees in a modified Petri dish sprayed with $0.07 \%$ Deltamethrin (DTT) (Pirisa-PiretroIndustrial Ltda, Brazil) were included as positive death control. Four replicates for each experimental group were run. Bioassay dishes were placed in incubators at 28 $\pm 1{ }^{\circ} \mathrm{C}$ and $60 \%$ relative humidity. Mortality of bees was evaluated daily, by visual inspection for a period of 15 days.

\section{STATISTICAL ANALYSIS}

Differences in survival after 15 days of observation were assessed by Kaplan-Meier analysis followed by the Logrank test. A p value $<0.05$ was considered statistically significant. All statistical analyses were performed with the software package GraphPadPrism 4.00 for Windows (GraphPad Software, San Diego, CA, USA).

\section{RESULTS}

P. larvae SUsceptibility TeST AND DETERMINATION OF MICS

The $P$. larva was susceptible to the assessed crude extract of the $C$. officinalis and $N$. officinale. For the $C$. domestica, only the EtAc and $\mathrm{BuOH}$ fractions indicated activity against $P$. larvae. The MICs of these samples ranged from 0.98-30.51 $\mathrm{mg} / \mathrm{mL}$, and the crude extract and DCM fraction of $C$. domestica did not show activity against $P$. larvae (Table I).

\section{TABLE I}

MICs of $C$. officinalis, $N$. officinale and $C$. domestica on P. larvae.

\begin{tabular}{lc}
\hline \multicolumn{1}{c}{ Extract or fraction } & MICs on P. larvae $(\mathrm{mg} / \mathrm{mL})$ \\
\hline C. officinalis crude extract & 12.76 \\
N. officinale crude extract & 30.51 \\
C. domestica crude extract & - \\
C. domestica DCM fraction & - \\
C. domestica EtAc fraction & 4.06 \\
C. domestica BuOH fraction & 0.98 \\
\hline
\end{tabular}

\section{TOXICITY ASSAY IN BEES}

Toxicity analysis in bees, evaluated by the spraying application method of $C$. officinalis, $N$. officinale crude extracts, and EtAc, $\mathrm{BuOH}$ fractions of $C$. domestica, showed no toxicity for $N$. officinale crude extract and $C$. domestica $\mathrm{BuOH}$ fraction during 15 days of treatment, however, some deaths of bees occurred during the first three days of treatment with $C$. officinalis and $C$. domestica EtAc fraction (Fig. 1). Bee mortality was evident in treatment with DTT (positive death control group).

\section{DISCUSSION}

The search for the discovery of drugs, as well as the determination of the prudent use of antimicrobial agents, are the basis to solve the global problem of microbial resistance; and the resources for the discovery of drugs are the natural products (Santos et al. 2012). 


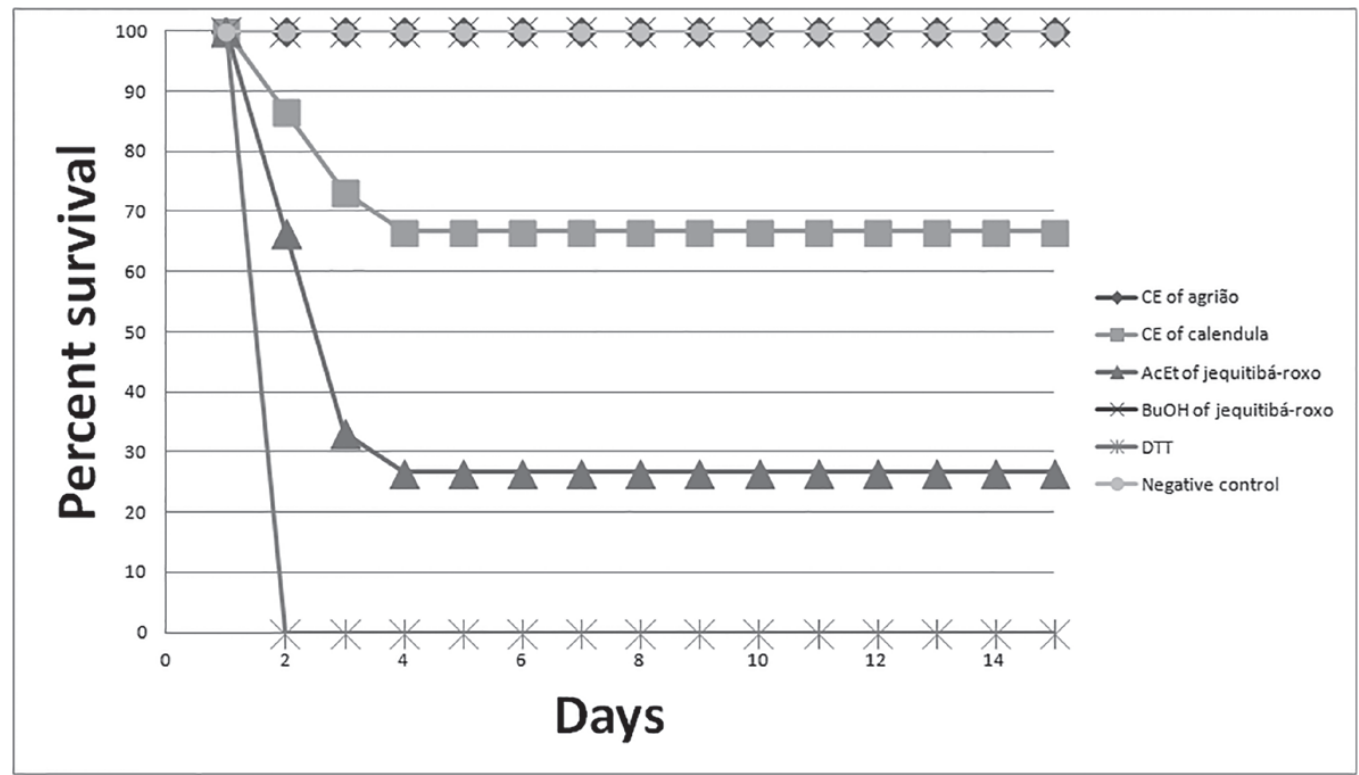

Figure 1 - Percentage of survival of bees subjected to spraying with $C$. officinalis (calendula) crude extract, $N$. officinale (agrião) crude extract, and C. domestica (jequitibá-roxo) EtAc and $\mathrm{BuOH}$ fractions. $\mathrm{CE}$ (crude extract).

The crude extracts of three Brazilian species were investigated: $N$. officinale, $C$. officinalis and $C$. domestica. The determination of the MIC through the method of broth micro dilution showed that only the crude extract of $N$. officinale and $C$. officinalis (Table I) exhibited an antibacterial effect against $P$. larvae, with respective MICs of 12.76 $\mathrm{mg} / \mathrm{mL}$ and $30.51 \mathrm{mg} / \mathrm{mL}$. Therefore these two species were not fractionated. The $C$. domestica crude extract did not show such activity, for this reason, its aqueous extract was fractionated using solvents of increasing polarity, with the objective of concentrating molecules with similar polarity in the same fractions and, consequently, promote better activities, as observed in Table I, in which low MIC values were found for AcEt and $\mathrm{BuOH}$ fractions of $C$. domestica.

One of the most usual problems in the use of medicinal plants is the amount of extract used. In this case the MIC values were between 0.98 and $30.51 \mathrm{mg} / \mathrm{mL}$, however this is not a serious problem, since the herbal products are relatively safer than synthetic drugs (Abubakar 2010). The MIC values obtained for the crude plant extracts were high when compared with the MIC values of $0.01-10 \mu \mathrm{g} / \mathrm{mL}$, frequently recorded for conventional antibiotics. The differences can be due to the fact that synthetic antibiotics are in a pure form, plants extracts don't act the same way as synthetic antibiotics, that's why were found high MIC values (Abubakar 2010).

To do the spraying on $A$. mellifera extracts or fractions that have shown activity against $P$. larvae were used in exactly the same concentration, in order to verify, by the percentage of survival, the possible toxic effects (Fig. 1).

$N$. officinale crude extract and $C$. domestica $\mathrm{BuOH}$ fraction showed $100 \%$ survival in all periods analyzed, demonstrating no toxic effects at the concentrations tested.

The $C$. officinalis crude extract and C. domestica EtAc fraction showed, respectively, 66.68\% and $26.64 \%$ of survival in the concentration tested at the end of the experiment.

The $N$. officinale that showed good results have triterpenes, steroids, flavonoids, phenyl propanoids and saponins (Carvalho et al. 2009). Studies by Boligon et al. (2013) found in the crude extract of $N$. officinale $104.41 \mathrm{mg} / \mathrm{g}$ of phenols, $71.83 \mathrm{mg} / \mathrm{g}$ of flavonoids, 
and analyzed by HPLC-DAD showed chlorogenic acid (1.25\%), caffeic acid (5.08\%), and rutin (1.92\%). The antimicrobial activity of $N$. officinale has also been shown by Abu-Zinadah (2008).

In a similar study performed by Janovik et al. (2009), the C. domestica showed that in the $\mathrm{BuOH}$ fractions had $486.22 \mathrm{mg} / \mathrm{g}$ of polyphenols and $15.26 \mathrm{mg} / \mathrm{g}$ of flavonoids, and in the EtAc fraction had $510 \mathrm{mg} / \mathrm{g}$ of polyphenols and $39.92 \mathrm{mg} / \mathrm{g}$ of flavonoids. In this same study the EtAc fraction also presented: gallic acid $(2.5 \mathrm{mg} / \mathrm{g})$, caffeic acid $12.82(\mathrm{mg} / \mathrm{g})$, chlorogenic acid $(15.27 \mathrm{mg} / \mathrm{g})$, rutin (11.45), and kanferol (0.85 mg/g).

For C. officinalis, the chemical constituents include some triterpene saponins, triterpene alcohols, triterpene esters, carotenoids such as flavoxanthin, lutein, rubixanthin, $\beta$-carotene, and lycopene (Pintea et al. 2003, Fonseca et al. 2010), flavonoids (quercetin, rutin, narcison, isorhamnetin and kaempferol) and coumarins (Fonseca et al. 2010).

A study performed by Ducat et al. (2011) showed that this species contains, $92.35 \mathrm{mg} / \mathrm{g}$ of phenolic acid and $13.55 \mathrm{mg} / \mathrm{g}$ of flavonoids in a 70\% ethanolic extract, and also showed an antimicrobial activity for Staphylococcus aureus and Klebsiella pneumoniae. Other study by Efstratios et al. (2012) showed antifungal and antibacterial activity against Bacillus subtilis, Escherichia coli, Enterococcus faecalis, Pseudomonas aeruginosa and Klebsiella pneumoniae.

These substances found in these species may be related to activities against $P$. larvae. The antimicrobial action of polyphenolics, including flavonoids, aromatic and phenolic acids, is frequently reported (Banskota et al. 2001). Specifically, Flesar et al. (2010) confirmed the antimicrobial activity against $P$. larvae of the naringenin (MIC 64 microgram $/ \mathrm{mL}$ ), caffeic acid $(>128$ microgram $/ \mathrm{mL})$, quercetin dihydrate $(>128)$ catechin $(>128)$ among other phenolic compounds.

It has been proposed that the antimicrobial activity could be due to synergism between the various components. It was observed that none of the single component showed a higher activity than the total extract (Bonvehi et al. 1994, Flesar et al. 2010, Boligon et al. 2013).

Similarly, the antibacterial activity of the propolis extract could be related with its chemical composition, which includes phenolic compounds (flavonoids and aromatic acids), terpenes and essential oils among others (Sforcin 2007, Antúnez et al. 2008).

A very similar study of Boligon et al. (2013) evaluated the antimicrobial susceptibility of the $P$. larvae to the crude extract, dichloromethane, EtAc and $\mathrm{BuOH}$ fractions of the $S$. buxifolia, where the MICs were 50, 1.56, 6.25, $25 \mathrm{mg} / \mathrm{mL}$, respectively. The antimicrobial activity was related to the chemical composition of the S. buxifolia which is rich in steroids, triterpenes, phenolic compounds, flavonoids and alkaloids (Boligon et al. 2013). In the same study, in the toxicity assay by spraying, S. buxifolia showed not be toxic for bees during 15 days.

However, the same did not occur with $C$. officinalis, this species showed an acute toxicity and growth inhibition in milkweed bug, Oncopeltus fasciatus Dallas. Also, Calendula micrantha officinalis showed molluscicidal activity (AbdEl-Megeed 1999). These important activities can explain the mortality of bees with $C$. offinalis crude extract in this study.

Janovik et al. (2009) isolated lupeol, $\beta$-amyrin, $\beta$ - sitosterol and stigmasterol fraction of $C$. domestica EtAc and also the same compounds of Inula japonica, which showed acaricidal effect in vitro against carmine spider mite, Tetranychus cinnabarinus (Boisduval) in a study performed by Duan et al. (2011), this may explain the reason for the higher mortality in bees, even containing a large amount of polyphenols in this fraction.

Similarly, in a study conducted by Santos et al. (2012) with the sprinkling of Carapa guaianensis (andiroba) oil, only 20\% of bee survival was observed after 10 days, the insecticidal effect of andiroba oil was associated with this result. 
Plant extracts have a complex blend of different secondary metabolites that are an important source of bioactive molecules, some of them displaying important antibacterial effect for the drug-chemical and the food control (Flesar et al. 2010). Brazil has a rich biodiversity with numerous compounds that can contribute to bee's health; there are many promising species for future research involving alternative natural substances to control AFB.

The elimination of the P. larvae in A. mellifera colonies involves treatments with acceptable antimicrobial activity that do not present side effects on A. mellifera and that minimizes the residues in the honey (Santos et al. 2012).

The three Brazilian species tested and obtained in the collection sites described, showed for the first time, antimicrobial activity. The $N$. officinale crude extract and the $C$. domestica $\mathrm{BuOH}$ fraction both presented non toxic effects in the concentration tested.

Therefore, this species can be used in the practice of apiculture by pulverization and may also be a potential and useful alternative for the treatment or prevention of AFB.

\section{ACKNOWLEDGMENTS}

The authors are grateful for the financial support of Conselho Nacional de Desenvolvimento Científico e Tecnológico/Coordenação de Aperfeiçoamento de Pessoal de Nível Superior/Fundação de Amparo a Pesquisa do Rio Grande do Sul (CNPq/CAPES/ FAPERGS) /Brazil.

\section{RESUMO}

Loque americana é uma grave doença de propagação mundial em abelhas causada pelo Paenibacillus larvae. Extratos de plantas são conhecidos por diminuir ou inibir o crescimento dessa bactéria. O objetivo deste estudo foi avaliar a atividade antimicrobiana dos extratos de Calendula. officinalis, Cariniana domestica, e Nasturtium officinale contra o P. larvae e avaliar a toxicidade dos extratos em abelhas. A atividade in vitro dos extratos contra P. larvae foi avaliada pelo método de microdiluição e as concentrações inibitórias mínimas (MICs) também foram determinadas. As concentrações utilizadas no ensaio de toxicidade foram estabelecidas baseadas nos valores de MIC e pelo método de aplicação por pulverização. O P. larvae foi suscetível aos extratos brutos de $C$. officinalis e $N$. officinale avaliados. Para a C. domestica, apenas as frações acetato de etila (EtAc) e butanólica $(\mathrm{BuOH})$ tiveram atividade contra P. larvae. Análises de toxicidade em abelhas não mostraram toxidade para o extrato bruto de $N$. officinale e fração $\mathrm{BuOH}$ de $C$. domestica durante os 15 dias de tratamento, no entanto, ocorreram algumas mortes de abelhas durante os três primeiros dias de tratamento com $C$. officinalis e fração EtAc de C. domestica. Os resultados com essas espécies foram pela primeira vez descritos e mostraram que o extrato bruto de $N$. officinale e a fração $\mathrm{BuOH}$ de $C$. domestica ambos não apresentaram efeitos tóxicos nas concentrações testadas pelo método de aplicação por pulverização e podem ser uma alternativa útil para o tratamento ou prevenção da loque americana.

Palavras-chave: atividade antibacteriana, loque americana, plantas brasileiras, Paenibacillus larvae.

\section{REFERENCES}

ABD-EL-MEGEED KN. 1999. Studies on the molluscicidal activity of Calendula micrantha officinalis (Compositae) on fascioliasis transmitting snails. J Egypt Soc Parasitol 29: 183-192.

ABUBAKAR EM. 2010. Antibacterial potential of crude leaf extracts of Eucalyptus camaldulensis against some pathogenicbacteria. Afr J Plant Sci 4: 202-209.

ABU-ZINADAH OA. 2008. Effects of watercress oil on the thermal and chemical burn injuries in rabbits. JKAU: Med Sci 15: 3-17.

Antúnez K, Harriet J, Gende L, Maggi M, Eguaras M AND ZUNINO P. 2008. Efficacy of natural propolis extract in the control of American Foulbrood. Vet Microbiol 131: 324-331.

Banskota AH, Tezuka Y And Kadota S. 2001. Recent progress in pharmacological research of propolis. Phytother Res 15: 561-571.

BAstos EMAF, Simone M, JoRGE DM, SOARES AEE AND SPIVAK M. 2008. In vitro study of the antimicrobial activity of Brazilian propolis against Paenibacillus larvae. J Invertebr Pathol 97: 273-281.

BogdanOv S. 2006. Contaminants of bee products. Apidologie 37: 1-18. 
Boligon AA, Brum TF, Zadra M, Piana M, Alves CFS, FAUSTO VP, BARBOZA JÚNIOR VS, VAUCHER RA, SANTOS RCV AND ATHAYDE ML. 2013. Antimicrobial activity of Scutia buxifolia against the honeybee pathogen Paenibacillus larvae. J Invertebr Pathol 112: 105-107.

Bonvehi SJ, Ventura CF AND Escola JR. 1994. The composition, active components and bacteriostatic activity of propolis on dietetics. J Am Oil Chem Soc 71: 529-532.

Carvalho JLS, Cunico MM, Dias JFG, Miguel MD AND MiguEL OG. 2009. Termoestabilidade de processos extrativos de Nasturtium officinale R. Br., Brassicaceae por sistema Soxhlet modificado. Quím Nova 32: 1031-1035.

CLSI. 2008. Methods for Dilution Antimicrobial Susceptibility Tests for Bacteria that Grow Aerobically, ninth ed. Approved standard M7-A6. Clinical and Laboratory Standards Institute, Wayne (PA).

COX B, GRAHAM H AND EISCHEN F. 2005. American foulbrood survey in honey bees pollinating California almonds. Part I of three parts - widespread incidence of AFB spores. Am Bee J 145: 302-304.

DuAn D, Bu CY, Cheng J, WANG YN AND ShI GL. 2011. Isolation and Identification of Acaricidal Compounds in Inula japonica (Asteraceae) D Econ Entomol 104: 375-378.

DUCAT G, TORRES YR, SANTA HSD, CAETANO IK, KLEINUBING SA, STOCK D, TUSSOLINI L, JUSTO TH AND QUINÁIA. SP. 2011. Correlation among metallic ions, phenolic compounds and antimicrobial action in medicinal plants extracts. J Food Quality 34: 306-314.

Efstratiou E, Hussain AI, Nigam PS, Moore JE, Ayub MA AND RAO JR. 2012. Antimicrobial activity of Calendula officinalis petal extracts gainst fungi, as well as Gram-negative and Gram-positive clinical pathogens. Complement Ther Clin Pract 18: 173-176.

Eguaras MJ, Fuselli S, Gende L, Fritz R, RufFinengo SR, Clement G, Gonzalez A, Bailac PN and Ponzi MI. 2005. An in vitro evaluation of Tagetes minuta essential oil for the control of the honeybee pathogens Paenibacillus larvae and Ascosphaera apis, and the parasitic mite Varroa destructor. J Essent Oil Res 17: 336-340.
Flesar J, HAVLIK J, KLOUCEK P, RADA V, TITERA D, BEDNARM M, STROPNICKY M AND KOKOSKA L. 2010. In vitro growthinhibitory effect of plant-derived extracts and compounds against Paenibacillus larvae and their acute oral toxicity to adult honey bees. Vet Microbiol 145: 129-133.

FonseCA YM, VICENTINI FTMC, CATINI CD AND FONSECA MJV. 2010. Determination of rutin and narcissin in marigold extract and topical formulations by liquid chromatography: applicability in skin penetration studies. Quim Nova 33: 1320-1324.

HANSEN H AND BRøDSGAARD CJ. 1999. American foulbrood: a review of its biology, diagnosis and control. Bee World 80: 5-23.

Hayouni EA, BouIX M, ABEDRABBA M, LEVEAUM JY AND HAMDIM M. 2008. Mechanism of action of Melaleuca armillaris (Sol. Ex Gaertu) Sm. essential oil on six LAB strains as assessed by multiparametric flow cytometry and automated microtiter-based assay. Food Chem 111: 707-718.

JANOVIK V, BOLIGON AA, BANDEIRA RV AND ATHAYDE ML. 2009. HPLC/DAD analysis, determination of total phenolic and flavonoid contents and antioxidants activity from the Leaves of Cariniana domestica (Mart) Miers. Research J Phytochem 5: 209-215.

Kochansky J, KnOX DA, Feldlaufer M AND Pettis JS. 2001. Screening alternative antibiotics against oxytetracycline-susceptible and -resistant Paenibacillus larvae. Apidologie 32: 215-222.

LEWIS K AND AUSUBEL FM. 2006. Prospects for plant-derived antibacterials. Nat Biotechnol 24: 1504-1507.

Pintea A, Bele C, ANDREi S AND Socaciu C. 2003. HPLC analysis of carotenoids in four varieties of Calendula officinalis L. flowers. Acta Biologica Szegediensis 47: 37-40.

SANTOS RCV, ALVES CFS, SCHNEIDER T, LOPES LQS, AURICH C, Giongo JL, BRAndelli A AND VAUCHER RA. 2012. Antimicrobial activity of Amazonian oils against Paenibacillus species. J Invertebr Pathol 109: 265-268.

SFORCIN JM. 2007. Propolis and the immune system: a review. J Ethnopharmacol 113: 1-14. 
